\title{
Acute Acalculous Cholecystitis Complicating the Course of Infectious Mononucleosis
}

\author{
Elda Skenderi MD ${ }^{1}$, Gjeorgjina Kuli-Lito ${ }^{2}$ \\ ${ }^{1}$ Pediatrician, Pediatric Hospital, University Hospital Center “Mother Teresa”, Tirana, Albania \\ ${ }^{2} \mathrm{PhD}$, Professor, Researcher, Lecturer, University Hospital Center "Mother Teresa", Tirana, Albania
}

\begin{abstract}
Infectious Mononucleosis is the most common medical condition caused by Epstein-Barr virus (EBV). EBV is a member of the family Herpesviridae widely prevalent in nature and infects $>95 \%$ of the world's population. EBV establishes lifelong latent infection after the primary illnes, memory B cells are the reservoir for EBV in the body. Fatigue, fever, pharyngitis, lymphadenopathy and splenomegaly are the mayor clinical manifestations of Infectious Mononucleosis. Hepatic inflammation probably due to infiltration of cytotoxic T lymphocytes with mild, transient elevations in serum aminotransferases is often reported and mild jaundice is found in $5 \%$ of cases. Acute acalculous cholecystitis is the inflammation of gallbladder without the presence of calculi. This is uncommon in children and is usually caused by infections and rarely follow abdominal trauma, burn injury or associate systemic vasculitis. AAC complicating the course of Infectious Mononucleosis is rarely reported in children but is associated with favorable outcome, all cases recovered with medical treatment. We report the case of a 8 years female patient with AAC during the course of IM and review of the literature.
\end{abstract}

Keywords: Acute Acalculous Cholecystitis, Infectious Mononucleosis, EBV virus, gallbladder, ultrasonography

\section{Introduction}

Infectious Mononucleosis was the name chosen by Sprunt and Evans in 1920 to describe a syndrome that resembled an acute infectious disease accompanied by atypical large peripheral blood lymphocytes (25). Epstein-Barr virus (EBV) was first discovered in 1964 by electron microscopy of suspension cultures o African Burkitt lymphoma cells (4). Four years later, EBV was linked to Infectious Mononucleosis, which is it mayor clinical manifestation (8). As other human herpesviruses EBV after its acquisition results in lifelong infection once viral replication has been contained, it's estimated that $>90 \%$ of adults worldwide has antibodies against it (22). Initial infection is thought to occur in the oral compartment, the host cells of EBV are mainly B lymphocytes and epithelial cells (16). Humans are the only known reservoir of EBV in the nature. Young children most likely acquire EBV primary infection from close contact that involves exchange of oral secretions via shared items such as toys, bottles and utensils. Before the age of 10, primary infection is usually asymptomatic or produce an acute illness that is often not recognized as being due to EBV (27). Healthy people continue to shed EBV for many months after their acute infection and are potentially capable of transmitting it $(1,6)$.Infectious Mononucleosis most commonly begin insidiously, with vague malaise, followed several days later by fever, sore throat, swollen posterior cervical lymph nodes, and fatigue, some patients experience an abrupt onset influenza-like, with fever, chills, body aches and sore throat. $(5,7,9,17,20)$.Abnormal liver function tests is found in $80 \%$ of cases so it is considered as part of the disease rather than a complication. Liver inflammation is subclinical in approximately $95 \%$ of cases and 5\% develop jaundice and complain of tenderness on the right upper quadrant of the abdomen probably due to hepatic swelling and pressure on the liver capsule. The mean duration of Infectious Mononucleosis is 16 days, which is much longer than the duration of most acute viral illnesses, recovery is gradual and it may take months for the patient to feel well (20).Complications may be due to virus invasion of the tissues or immune-mediated damage. Many complications are associated with EBV most of them are uncommon or rare: airway obstruction, meningoencephalitis, hemolytic anemia, thrombocytopenia, splenic rupture, other neurologic disease, psychological disorders $(2,10,14,21,29)$. EBV has oncogenic properties, it is associated with lymphoproliferative disorders and neoplastic disease, including Burkitt's lymphoma and nasopharyngeal carcinoma. Acute acalculous cholecystitis is the inflammation of gallbladder without the presence of calculi. This condition is uncommon in children usually is caused by infections or follow abdominal trauma, burn injury or associate systemic vasculitis. We describe a case of AAC during the course of Infectious Mononucleosis.

\section{Case Report}

A 8-year-old female admitted to the University Hospital Center of Tirana suspected for hepatitis. Before visiting our hospital she was treated by a local clinic for purulent tonsillitis with amoxycilin, 5 days after this treatment she presented fever, abdominal pain, dark color urine and yellow coloration of sclera. She did not reported any familiar history of hepatitis. On physical examination she appeared ill. Scleral icterus was present. The pharynx was injected and tonsils covered with exudates. Cervical lymph nodes were not palpable. Maculo-papular rash was present on the skin most prominent over the trunk. The abdomen was soft not distended, bowel sounds were present. The right side of the abdomen was tender with fullness on the right hypocondrium indicating a positive Murphy's sign. No spleno-megaly, no evidence of free fluid was noticed in the abdomen.

Laboratory investigations on admission revealed a blood cell count WBC 13300 (35\% lymphocytes), RBC 4360000 , 


\section{International Journal of Science and Research (IJSR) \\ ISSN (Online): 2319-7064 \\ Index Copernicus Value (2013): 6.14 | Impact Factor (2014): 5.611}

hemoglobin level $12.1 \mathrm{~g} / \mathrm{dl}$, hematocrit value $36.5 \%$, platelet count 202000, aspartat aminotransferase (AST) 400U/L (nr 0-35U/L), alanin aminotransferase (ALT) 398U/L (nr 045U/L), gamma-glutamyltransferase (GGT) 199U/L ( $\mathrm{nr} 0-$ $55)$, total serum bilirubin $3.62 \mathrm{mg} / \mathrm{dl} \quad(0.3-1.2 \mathrm{mg} / \mathrm{dl})$, prothrombin time/international normalized ratio (INR) 1.14, blood urea nitrogen $30 \mathrm{mg} / \mathrm{dL}(\mathrm{nr} 10-43 \mathrm{mg} / \mathrm{dL})$, creatinin level $0.5 \mathrm{mg} / \mathrm{dL}$ ( $\mathrm{nr} 0.6-1.4 \mathrm{mg} / \mathrm{dL}$ ), serum total protein level $6.8 \mathrm{~g} / \mathrm{dL}(\mathrm{nr} 6-8 \mathrm{~g} / \mathrm{dL})(\mathrm{Tab} 1)$

Abdominal ultasonography showed diffuse edematous thickening of the gallbladder (6 $\mathrm{mm}$ thickeness) with increased vascularity and absence of sludge, stones or dilatation of the biliary tract (Fig 1). Sonographic Murphy's sign was positive. Laboratory research of hepatitis A, B and $\mathrm{C}$ virus including $\mathrm{HBsAg}$, anti-hepatitis A virus IgM, antihepatitis $\mathrm{C}$ virus were negative. Ceruloplasmine levels were normal $0.416 \mathrm{~g} / \mathrm{L}$ (nr $0.2-0.6 \mathrm{~g} / \mathrm{L}$ ) excluding Wilson disease. The EBV panel result indicated acute primary infection: IgM antibodies against viral capsid antigen (VCA) were positive $62.49 \mathrm{arbU} / \mathrm{ml}$ (neg $<10 \mathrm{arbU} / \mathrm{ml}$ ), whereas VCA- IgG antibodies were negative $1.6 \mathrm{arbU} / \mathrm{ml}$ (neg $<5 \mathrm{arbU} / \mathrm{ml}$ ).

Once the diagnosis of Infectious Mononucleosis was confirmed intravenous rehydration therapy with glucose and electrolyte solution was started antibiotic treatment with cephalosporin was continued until EBV serology results were obtained. Gastrointestinal symptoms such as abdominal pain and nausea ameliorated gradually, fever subsided on the fourth day of admission, gall bladder abnormality resolved and she was discharged 10 days after admission.

Table 1: Clinical course of the patient

\begin{tabular}{|c|c|c|c|c|c|}
\hline Hospital day & 1 & 2 & 4 & 6 & 10 \\
\hline AST/ALT(U/L) & $400 / 335$ & $345 / 318$ & $295 / 226$ & $259 / 192$ & $208 / 179$ \\
\hline Total bilirubin(direct bilirubin mg/dL) & 3.62 & 3.3 & $2.2(0.9)$ & 1.8 & 1.3 \\
\hline Gamma-glutamyltransferase U/L & 199 & & 150 & & 59 \\
\hline WBC & 13300 & 12000 & & 8900 & \\
\hline Lymphocytes & 35 & 66.6 & & 66.6 & \\
\hline Hemoglobin & 12.1 & 9.7 & & 10.2 & \\
\hline Platelet & 202000 & 163000 & & 226000 & \\
\hline
\end{tabular}

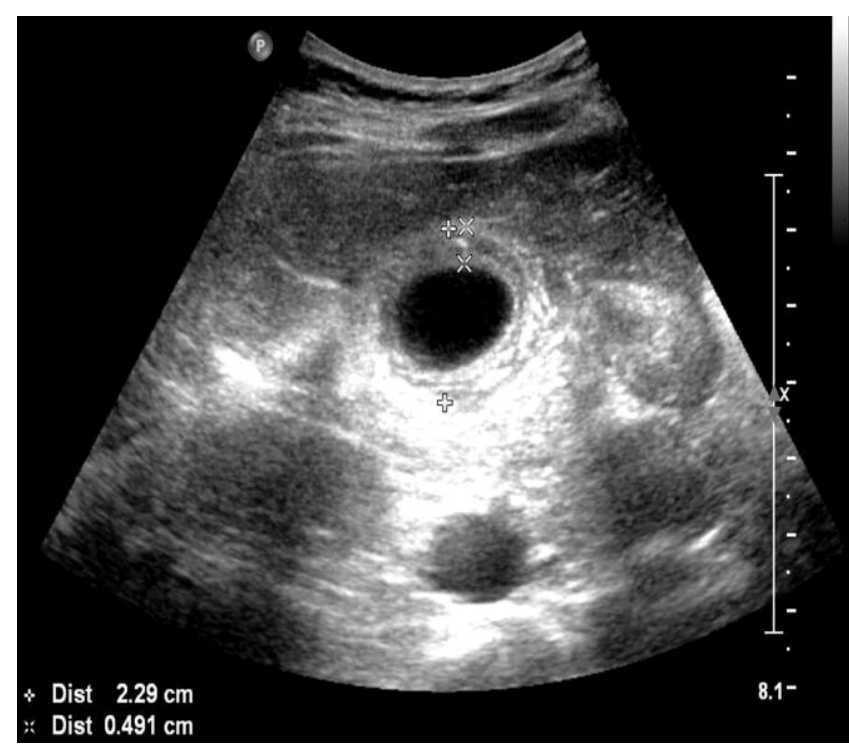

Figure 1: Abdominal sonography taken on admission, showing gallbladder wall thickening $6 \mathrm{~mm}$ in a striated pattern without echogenic calculi

\section{Discussion}

EBV is one of the viruses that causes hepatitis, severe hepatocelular injury is rare and it pathogenesis is uncertain $(15,18)$. Mild transient elevation in serum aminotransferases is commonly reported and mild jaundice is reported in 5\% of cases possibly as a result of cholestasis or virus-induced hemolysis (14).

Gallbladder disease is rare in children and cholecystitis is rarely considered in childhood acute abdominal pain (11). $\mathrm{AAC}$ is the inflammation of gallbladder in the absence of stones and accounts for $30-50 \%$ of pediatric cholecystitis
(18). The pathogenesis of AAC is mainly related to decreased blood flow to the gallbladder, obstruction of the biliary tract or increased viscosity of the bile (11). AAC in children most commonly occurs during the course of infectious disease such as streptococci group A and B, gram negative organisms, hepatitis A virus, EBV, Leptospira interrogans, Salmonella typhi, parasitic infestations with Ascaris or Giardia lamblia, or may associate infective endocarditis or systemic disease such as Kawasaki disease (26). AAC has also been reported to occur in other medical conditions such as abdominal trauma, extensive burns, and long term total-parenteral nutrition (26). Congenital gallbladder anomalies, congenital biliary duct anomalies and acquired disorders causing biliary stasis are also associated with childhood cholecystitis (23).

The association between EBV infection and AAC has been previously reported in children but is described as an uncommon condition (18). The diagnosis of acute cholecystitis is based on physical and radiological findings whereas EBV infection is based on serologic results. The clinical presentation of childhood AAC is not specific but similar to other abdominal inflammatory disease. Usually patients present with fever, jaundice, RUQ or epigastric pain which is less localized in younger children, nausea and vomiting. Ultrasonography is the main diagnostic modality of AAC $(19,13)$. Ultrasonographic findings in AAC include gallbladder wall thickening of at least $3.5 \mathrm{~mm}$, globular distention of the gallbladder, sludge, pericholecystic fluid and striated gallbladder wall. A combination of at least two of the above mentioned findings are considered to indicate AAC (3).

Treatment of AAC includes serial examinations, gallbladder ultrasonography and cholecystectomy when indicated by

\section{Volume 4 Issue 12, December 2015}




\section{International Journal of Science and Research (IJSR) \\ ISSN (Online): 2319-7064 \\ Index Copernicus Value (2013): 6.14 | Impact Factor (2014): 5.611}

deteriorating clinical and ultrasound findings. Treatment of choice of AAC in adults is cholecystectomy, exact criteria for the time of intervention have not been established (24, 12). In children initial conservative treatment of AAC is safe and effective in most cases (11).

\section{Conclusion}

Our case confirms that the course of acute Infectious Mononucleosis may be complicated by Acute Acalculous Cholecystitis. This condition is rarely found in pediatric population. Ulrtasonography is the most accurate modality to confirm the diagnosis. The prognosis is good most cases recover with conservative therapy without needing surgical intervention.

\section{References}

[1] Balfour, H. H., Jr., et al. 2005. A prospective clinical study of Epstein-Barr virus and host interactions during acute infectious mononucleosis. J. Infect. Dis. 192:1505-1512. [PubMed]

[2] Connelly, K. P., and L. D. DeWitt. 1994. Neurologic complications of infectious mononucleosis. Pediatr. Neurol. 10:181-184. [PubMed]

[3] Deitch EA, Engel JM. Acute acalculous cholecystitis. Ultrasonic diagnosis. Am J Surg. 1981;142:290-292. [PubMed]

[4] Epstein, M. A., B. G. Achong, and Y. M. Barr. 1964. Virus particles in cultured lymphoblasts from Burkitt's lymphoma. Lancet i:702-703. [PubMed]

[5] Evans, A. S. 1978. Infectious mononucleosis and related syndromes. Am. J. Med. Sci. 276:325-339. [PubMed]

[6] Fafi-Kremer, S., et al. 2005. Long-term shedding of infectious Epstein-Barr virus after infectious mononucleosis. J. Infect. Dis. 191:985-989. [PubMed]

[7] Grotto, I., et al. 2003. Clinical and laboratory presentation of EBV positive infectious mononucleosis in young adults. Epidemiol. Infect. 131:683-689. [PMC free article] [PubMed]

[8] Henle, G., W. Henle, and V. Diehl. 1968. Relation of Burkitt's tumor-associated herpes-type virus to infectious mononucleosis. Proc. Natl. Acad. Sci. U. S. A. 59:94-101. [PMC free article] [PubMed]

[9] Hoagland, R. J. 1960. The clinical manifestations of infectious mononucleosis: a report of two hundred cases. Am. J. Med. Sci. 240:55-63. [PubMed]

[10] Hoagland, R. J., and H. M. Henson. 1957. Splenic rupture in infectious mononucleosis. Ann. Intern. Med. 46:1184-1191. [PubMed

[11]Huang SC, Yang YJ. Septic shock and hypofibrinogenemia predict a fatal outcome in childhood acute acalculous cholecystitis. J Pediatr Gastroenterol Nutr. 2011;53:548-552. [PubMed]

[12] Imamogu M, Sarihan H, Sari A, Ahmetoğlu A. Acute acalculous cholecystitis in children: Diagnosis and treatment. J Pediatr Surg. 2002;37:36-39. [PubMed]

[13] Imhof M, Raunest J, Ohmann C, Röher HD. Acute acalculous cholecystitis complicating trauma: a prospective sonographic study. World J Surg. 1992;16:1160-1165. [PubMed]
[14] Jenson, H. B. 2000. Acute complications of EpsteinBarr virus infectious mononucleosis. Curr. Opin. Pediatr. 12:263-268. [PubMed]

[15] Jimenez-Saenz, M., Perez-Pozo, J.M., Leal-Luna, A., and Herrerias-Gutierrez, J.M. Lethal liver failure in an elderly patient with hepatitis B superinfected with Epstein-Barr virus. Eur J Gastroenterol Hepatol. 2002; 14: $1283-1284$

[16] Kieff, E., and A. B. Rickinson. 2007. Epstein-Barr virus and its replication, p. 2603-2654. In D. M. Knipe, P. M. Howley, D. E. Griffin, R. A. Lamb, M. M. Martin, B. Roizman, and S. E. Straus (ed.), Fields virology, 5th ed., vol. II. Lippincott Williams \& Wilkins, Philadelphia, PA.

[17] McKinlay, C. A. 1935. Infectious mononucleosis. I. Clinical aspects. JAMA 105:761-764.

[18] Mendez-Sanchez, N., Aguilar-Dominguez, C., Chavez-Tapia, N.C., and Uribe, M. Hepatic manifestations of Epstein-Barr viral infection. Ann Hepatol. 2005; 4: 205-209

[19] Mirvis SE, Vainright JR, Nelson AW, Johnston GS, Shorr R, Rodriguez A, et al. The diagnosis of acute acalculous cholecystitis: a comparison of sonography, scintigraphy, and CT. AJR Am J Roentgenol. 1986;147:1171-1175. [PubMed]

[20] Rea, T. D., J. E. Russo, W. Katon, R. Ashley, and D. S. Buchwald. 2001. Prospective study of the natural history of infectious mononucleosis caused by EpsteinBarr virus. J. Am. Board Fam. Pract. 14:234-242. [PubMed]

[21] Robinson, R. G. 1988. Abdominal complications of infectious mononucleosis. J. Am. Board Fam. Pract. 1:207-210. [PubMed]

[22] Roizman, B. 1993. The family Herpesviridae: a brief introduction, p. 1-9. In B. Roizman, R. J. Whitley, and C. Lopez (ed.), The human herpesviruses. Raven Press, New York, NY.

[23] Sears HF, Golden GT, Horsley JS., 3rd Cholecystitis in childhood and adolescence. Arch Surg. 1973;106:651-653. [PubMed]

[24] Shin YH, Shin JI, Park JM, Kim JH, Lee JS, Kim MJ. A five-year-old boy with nephrotic syndrome complicated with acute acalculous cholecystitis. Pediatr Int. 2007;49:674-676. [PubMed]

[25] Sprunt, T. P., and F. A. Evans. 1920. Mononuclear leucocytosis in reaction to acute infections ("infectious mononucleosis"). Johns Hopkins Hosp. Bull. 31:410417.

[26] Suchy FJ. Disease of the gallbladder. In: Kliegman RM, editor. Nelson textbook of pediatrics. 19th ed. Philadelphia: Elsevier; 2011. pp. 1415-1416.

[27] Sumaya, C. V., W. Henle, G. Henle, M. H. Smith, and D. LeBlanc. 1975. Seroepidemiologic study of Epstein-Barr virus infections in a rural community. $\mathrm{J}$. Infect. Dis. 131:403-408. [PubMed]

[28] Tsakayannis DE, Kozakewich HP, Lillehei CW. Acalculous cholecystitis in children. J Pediatr Surg. 1996;31:127-130. [PubMed]

[29] White, L. R., and P. S. Karofsky. 1985. Review of the clinical manifestations, laboratory findings, and complications of infectious mononucleosis. Wis. Med. J. 84:19-25. [PubMed]Abstract 